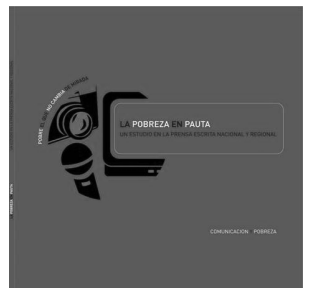

\title{
La Pobreza en Pauta. Un estudio en la prensa escrita NACIONAL Y REGIONAL.
}

Instituto de la Comunicación e Imagen y Alianza Comunicación y Pobreza

Santiago de Chile, 2006

\section{Claudia Farfán}

La pobreza no es sólo un problema material, sino de integración social. En ese sentido, no sólo es importante atender la calidad de la discusión sobre asuntos públicos, sino quiénes y cómo generan ese intercambio, y cómo en él se incluye a los chilenos más postergados. En una sociedad tan fragmentada como la nuestra, en donde los sectores de la población están distanciados no sólo por su nivel de ingresos económicos, sino también espacialmente, existe un ficticio diálogo entre sus ciudadanos. $\mathrm{Y}$ es precisamente en el proceso de re-conocer al "otro" como una pieza más del plural engranaje llamado sociedad, que los medios de comunicación juegan uno rol integrador.

En La Pobreza en Pauta, se explora cómo los medios de comunicación escritos abordan la pobreza, en cuanto a la cobertura y tratamiento periodístico a nivel nacional, y también regional, incluyendo a Atacama y La Araucanía. Una de las conclusiones significativas del estudio dice relación con las diferencias detectadas en los tratamientos editoriales y periodísticos de los medios analizados. Se constata la escasa presencia de noticias sobre pobreza en los diarios a nivel nacional versus una mayor cobertura en regiones. En tanto, en ambos casos, las notas periodísticas fueron "asociadas" a la pobreza y no "centradas" en el problema, es decir, su tema principal no fue la pobreza en sí, sino que se aludía a ésta a través de otros temas como educación, salud, vivienda y empleo. En definitiva, pese a que existe una diferencia entre lo nacional y lo regional en cuanto a cobertura, existen pautas de trabajo editoriales comunes.

Respecto a las voces y sujetos de la noticias, la ausencia de las personas en situación de pobreza es mayoritaria, por lo que en la construcción del relato su opinión y punto de vista queda al margen, al igual que las personas que los representan como es el caso de los dirigentes sociales. En la misma línea, el estudio revela que al analizar la actitud con que las noticias mostraban a la población en situación de pobreza, en un $56 \%$ en diarios nacionales y un $43 \%$ en regiones, "los 
pobres" son mostrados como receptores de ayudas o beneficios, es decir, con una actitud pasiva frente al problema.

Junto con el planteamiento de constataciones, La Pobreza en Pauta insta a cuestionamientos sobre el tema, abriendo la puerta al desarrollo de nuevas investigaciones: ¿Por qué algunos medios logran visualizar mejor a las personas en situación de pobreza que otros? ¿Cuál es la razón para la ausencia de los actores políticos en la discusión de los temas centrados o asociados a pobreza? ¿Por qué es el gobierno quien concentra las vocerías sobre estos asuntos públicos? Sin duda, la preocupación por las personas en situación de pobreza a nivel político no se ha traducido todavía en una priorización mediática significativa que permita enriquecer el debate sobre las estrategias de inclusión social. 